\title{
Uma outra representação da Rua Nova dos Mercadores, em Lisboa: a tábua do "martírio de S. Sebastião", de Gregório Lopes
}

Another representation of the Rua Nova dos Mercadores, in Lisbon: the Martyrdom of St. Sebastian by Gregório Lopes

\section{Luísa Trindade}

\section{OpenEdition}

\section{Journals}

\section{Edição electrónica}

URL: http://journals.openedition.org/medievalista/1180

DOI: $10.4000 /$ medievalista. 1180

ISSN: $1646-740 X$

\section{Editora}

Instituto de Estudos Medievais - FCSH-UNL

\section{Refêrencia eletrónica}

Luísa Trindade, « Uma outra representação da Rua Nova dos Mercadores, em Lisboa: a tábua do "martírio de S. Sebastião", de Gregório Lopes », Medievalista [Online], 20 | 2016, posto online no dia 01 dezembro 2016, consultado no dia 06 maio 2019. URL : http://journals.openedition.org/ medievalista/1180; DOI : 10.4000/medievalista.1180

(C) IEM 
Título / Title: Uma outra representação da Rua Nova dos Mercadores, em Lisboa: a tábua do "martírio de S. Sebastião", de Gregório Lopes /

Another representation of the Rua Nova dos Mercadores, in Lisbon: the Martyrdom of St.

Sebastian by Gregório Lopes

Autor(es) / Author(s): Luísa Trindade

Universidade / University: Universidade de Coimbra

Faculdade e Departamento / Unidade de Investigação - Faculty and Department /

Research Center - Faculdade de Letras, Departamento de História, Estudos Europeus,

Arqueologia e Artes / Centro de Estudos Sociais

Código Postal / Postcode: 3004-530

Cidade / City: Coimbra

País / Country: Portugal

Email: luisa.trindade@fl.uc.pt

Fonte: Medievalista [Em linha]. Direc. Bernardo Vasconcelos e Sousa. Lisboa: IEM.

Disponível em:

http://www2.fcsh.unl.pt/iem/medievalista/MEDIEVALISTA20/trindade2004.html

ISSN: 1646-740X

Data recepção do artigo / Received for publication: 15 de Janeiro de 2016

Data aceitação do artigo / Accepted in revised form: 21 de Abril de 2016 


\section{Resumo}

A partir da constatação empírica da proximidade entre duas representações urbanas - a pintura da Rua Nova dos Mercadores, de Lisboa, pertencente à Kelmscott Manor Collection (c. 1570) e a arquitetura de fundo do Martírio de S. Sebastião, pintado por Gregório Lopes para a Charola do Convento de Cristo em Tomar (década de 1530) - e das conclusões que daí decorrem, revisitam-se algumas das mais emblemáticas representações iconográficas da cidade, as teses que suportam a sua identificação e a importância de que se revestem para o conhecimento dos espaços centrais da Lisboa quinhentista e, assim, da sua imagem, tão descrita quanto ainda deficientemente imaginada.

Palavras-chave: Rua Nova dos Mercadores, Lisboa, urbanismo quinhentista, D. Manuel I, Gregório Lopes

\section{Abstract}

From the empirical recognition of the connection between two urban representations the depiction of the Rua Nova dos Mercadores (New Street of Merchants), in Lisbon, belonging to the Kelmscott Manor Collection (c. 1570) and the background architecture of the Martyrdom of St. Sebastian, painted by Gregório Lopes for the Convent of Christ in Tomar (1530s) - and its subsequent conclusions, this paper revisits some of the most iconic iconographic representations of the city, the arguments that supports their identification and their importance for the knowledge of the central areas of the 16th century Lisbon, city so often described and yet so poorly imagined.

Keywords: Rua Nova dos Mercadores, Lisbon, 16th century urbanism, King Manuel I, Gregório Lopes 


\title{
Uma outra representação da Rua Nova dos Mercadores, em
}

\section{Lisboa: a tábua do “martírio de S. Sebastião”, de Gregório Lopes / Another representation of the Rua Nova dos Mercadores, in}

\section{Lisbon: the Martyrdom of St. Sebastian by Gregório Lopes*}

\author{
Luísa Trindade
}

Entre 1536 e 1539, o pintor régio Gregório Lopes realizava para a Charola do Convento de Cristo, em Tomar, uma tábua representando o martírio de S. Sebastião ${ }^{1}$. Integrada no âmbito da ampla reforma espiritual e material da casa religiosa, iniciada por D. Manuel e continuada por D. João III, a escolha do tema, de raízes profundas na tradição do ocidente medieval, terá, porventura, obedecido igualmente a razões de carácter circunstancial: em primeiro lugar, a proximidade espiritual à principal vocação do Santo, militar e "defensor da igreja", particularmente adequada a uma ordem monásticomilitar como a de Cristo, sobretudo num momento em que se revia a regra à luz dos princípios fundacionais do cristianismo; em segundo lugar, a renovada importância que a figura de S. Sebastião despertava na década de trinta do século XVI. Efetivamente, a devoção já longa a este mártir romano como protetor contra a peste, flagelo que por esses mesmos anos assolava o reino e, com especial violência, a capital, ganhava um novo alento com a chegada de uma importante relíquia: o braço de S. Sebastião que, supostamente saqueado a uma igreja milanesa, fora trazido de Roma para Lisboa em 1531. Do seu sucesso contra as epidemias, dá conta Francisco de Holanda quando, em 1571, refere os 40 anos que a cidade gozou de imunidade graças ao poder propiciatório

\footnotetext{
* O texto que agora se publica corresponde integralmente à comunicação apresentada à $1^{\mathrm{a}}$ edição dos Colóquios do Convento de Cristo [CCC]: Arquitetura e ornamento em Tomar. Fixação e mobilidade, realizada a 30 de Outubro de 2015, sob o título "Representações de Lisboa na Charola de Tomar: entre o real e o imaginário".

${ }^{1}$ Destinada a um dos altares pequenos da Charola, a pintura, a óleo sobre madeira de carvalho e medindo $119 \mathrm{~cm}$ de altura por $244 \mathrm{~cm}$ de largura, pertence hoje ao acervo do Museu Nacional de Arte Antiga, com o número de inventário 80 Pint. No local de origem encontra-se exposta uma reprodução fotográfica.
} 
Uma outra representação da Rua Nova dos Mercadores, em Lisboa:

a tábua do “martírio de S. Sebastião", de Gregório Lopes • Luísa Trindade

da referida relíquia ${ }^{2}$. É aliás a sua extrema relevância que, porventura, explica a lenda posta a circular logo no século XVII de que fora oferecida a D. João III pelo imperador Carlos V, seu cunhado ${ }^{3}$.

Desta tábua (Figura 1), já exaustivamente estudada no âmbito do universo pictórico por diversos autores ${ }^{4}$, interessa-me focar um aspeto particular do discurso formal: a arquitetura que, em plano de fundo, encerra o campo figurativo e serve de cenário ao martírio do Santo.

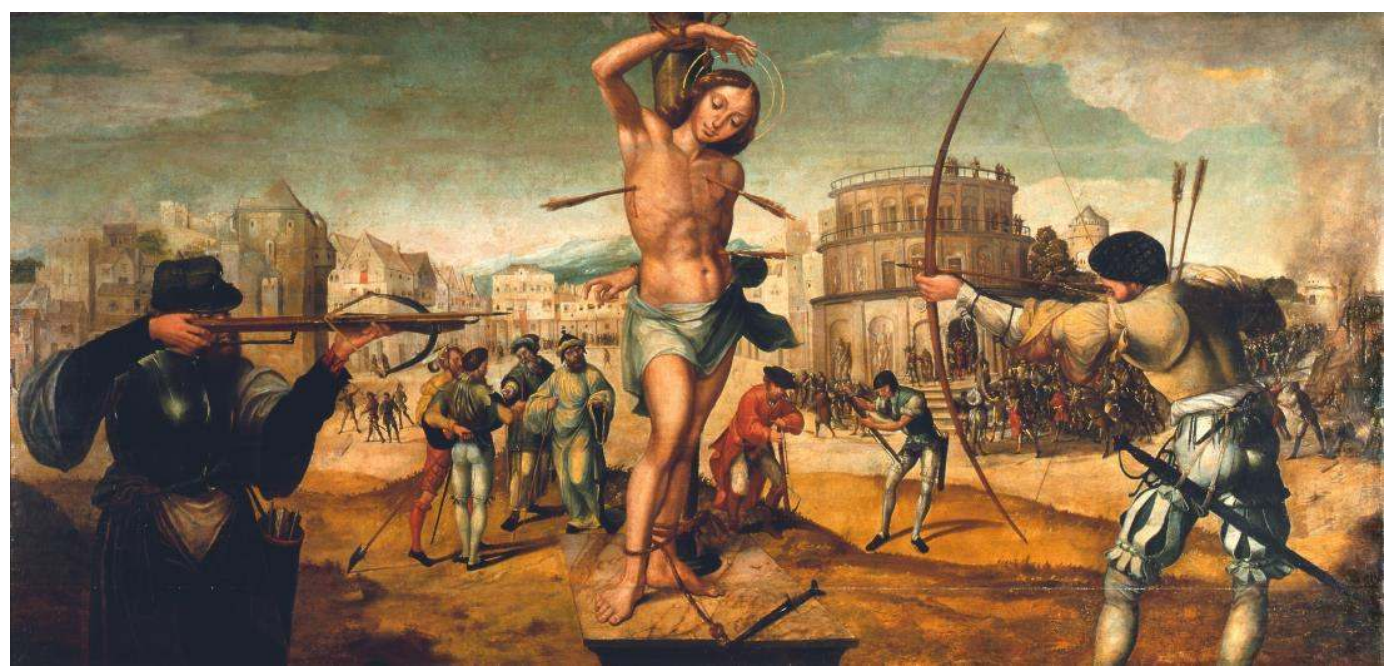

Figura 1 - Martírio de S. Sebastião, Gregório Lopes, 1536-1539.

Lisboa, Museu Nacional de Arte Antiga, Inv. 80 Pint.

De acordo com a tradição iconográfica, o episódio do primeiro martírio de S. Sebastião, atado a uma coluna ou árvore e rodeado de vários archeiros que sobre ele disparam uma intensa chuva de flechas, ocorre num espaço aberto com uma cidade por fundo. A partir

\footnotetext{
${ }^{2}$ HOLANDA, Francisco de - Da Fábrica que falece à cidade de Lisboa. Ed. José da Felicidade Alves (manuscrito de 1571, $1^{a}$ ed. de 1879). Lisboa: Livros Horizonte, 1984, p. 32.

${ }^{3}$ Contrariamente ao que é comum afirmar-se, a vinda da relíquia para Lisboa não terá qualquer ligação a Carlos V. Na realidade, a notícia da oferta imperial foi posta a circular por Frei Nicolau de Santa Maria, já no século XVII, sendo depois sistematicamente repetida por todos os autores. Para além de nada na documentação coeva o referir, se a origem fosse efetivamente essa, dificilmente se compreenderiam as comprovadas diligências de D. João III em inquirir da sua autenticidade junto do seu agente em Roma, Dr. Brás Neto. CARVALHO, José Adriano de Freitas - "Os recebimentos de relíquias em S. Roque (Lisboa 1588) e em Santa Cruz (Coimbra 1595). Relíquias e espiritualidade. E alguma ideologia". Via spiritus, n. 8 (2001), p. 105 ss.

${ }^{4}$ Garcês Teixeira, Vítor Serrão, José Luís Porfírio, Fernando António Baptista Pereira, Manuel Batoréo, José Alberto Seabra Carvalho e Joaquim de Oliveira Caetano são alguns dos autores essenciais para o conhecimento da obra de Gregório Lopes.
} 
do século $\mathrm{XV}$, e sobretudo por via italianizante, a urbe representada é usada para contextualizar espacialmente a narrativa: a cidade de Roma, palco do suplício do guarda pretoriano. Ruínas clássicas, pórticos e colunatas ou edifícios de grande porte e planta centrada, constituem um expediente comum aos pintores do renascimento que assim aliam à marcação espacial a oportunidade de evocar diretamente esse mundo aberto à pesquisa que era então a Antiguidade 5 . Opção menos frequente no norte da Europa, onde as arquiteturas fundeiras replicam preferencialmente as cidades flamengas em que se movem os próprios $\operatorname{artistas}^{6}$ (Figura 2).

Por vezes conjugam-se tempos e realidades diferentes como no martírio de S. Sebastião da autoria de Luca Signorelli (Figura 2) ${ }^{7}$, onde a cidade medieval surge inconfundível por entre múltiplas e imponentes ruínas romanas. E tal não se deve apenas ao "princípio de coetaneidade" 8 que tão frequentemente caracteriza as representações da época, particularmente visível, por exemplo, nas vestes ou cortes de cabelo das figuras. No caso do espaço urbano, e concretamente na representação do casario vulgar, a coetaneidade seria expectável se pensarmos que em 1498 o conhecimento da cidade clássica se reduzia praticamente aos edifícios de prestígio, as grandes ruínas ainda acessíveis, aliás entusiasticamente estudadas pelos próprios artistas modernos. A cidade comum, o casario em extensão, só a partir dos finais do século XVIII e das primeiras campanhas arqueológicas no Sul de Itália, seria minimamente conhecido.

\footnotetext{
${ }^{5}$ Veja-se, a título de exemplo, o Martírio de S. Sebastião, da autoria de Antonio del Pollaiuolo, de 1475, hoje na National Gallery, em Londres, ou o Martírio de S. Sebastião, de Andrea Mantegna, pintado em 1480 e pertencente ao acervo do Museu do Louvre, Paris.

${ }^{6}$ Caso do Martírio de S. Sebastião, de Hans Memling, pintado em torno de 1475 e pertencente às coleções dos Musées Royaux des Beaux-Arts, Bruxelas.

${ }^{7}$ Datado de 1498, pertence à Pinacoteca Comunale, Città di Castello.

${ }^{8}$ PEREIRA, Paulo - A Fábrica Medieval. Concepção e Construção da Arquitectura Portuguesa (11501550). Lisboa: Faculdade de Arquitetura da Universidade de Lisboa, 2011. Tese de Doutoramento. Vol. 1, p. 209. Sublinhe-se a importância fundamental desta obra para a compreensão das estratégias de representação dos pintores portugueses de Quinhentos.
} 


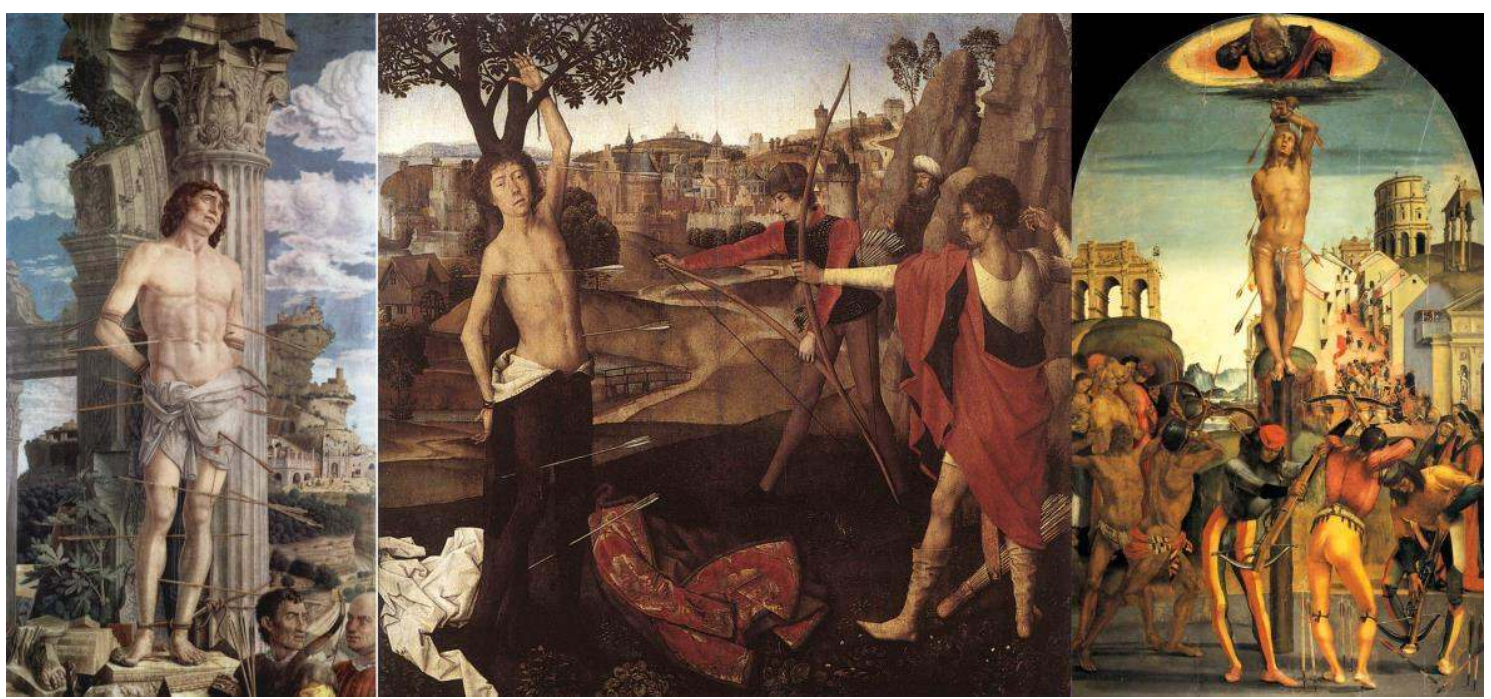

Figura 2 - Martírio de S. Sebastião, Andrea Mantegna, 1480. Paris, Museu do Louvre.

Martírio de S. Sebastião, Hans Memling, c. 1475. Bruxelas, Musées Royaux des Beaux-Arts.

Martírio de S. Sebastião, Luca Signorelli,1498. Città di Castello, Pinacoteca Comunale.

Também Gregório Lopes combina as duas tendências na sua tábua, a flamenga e a italiana, ou, de forma mais precisa, a cidade coeva e a cidade antiga. A estrutura narrativa divide-se em vários registos justapostos: três em profundidade, três outros em superfície. A cena principal ocupa o primeiro plano, com o Santo ao centro da composição, ladeado pelos seus algozes; Santo e coluna constituem um eixo vertical que divide a tábua em duas partes: à direita, toda uma estrutura formal que convoca a Roma das perseguições de Diocleciano, materializada na grande rotunda diretamente inspirada, como bem viu Paulo Pereira ${ }^{9}$, na edição de 1521 de César Cesariano do tratado de Vitrúvio, mas também pela visão longínqua de outros martírios que a coluna de fumo não deixa passar despercebidos ${ }^{10}$; na metade contrária, preenchendo todo $\mathrm{o}$ lado esquerdo do campo figurativo e despida de qualquer nota clacissizante, surge a cidade corrente ou do quotidiano, onde a vida parece decorrer indiferente ao drama que, simultaneamente, ocorre em primeiro plano.

\footnotetext{
${ }^{9}$ PEREIRA, Paulo - A Fábrica Medieval..., vol. I, p. 205.

${ }^{10}$ José Alberto Seabra de Carvalho coloca a hipótese desses martírios distantes serem, pelo contrário, uma referência direta à "perseguição antijudaica que varreu Lisboa em 1506 e que vivamente teria impressionado o pintor". CARVALHO, José Alberto Seabra de - Gregório Lopes. Pintura Portuguesa do século XVI. Lisboa: Edições Inapa, 1999, p. 62.
} 
Ora é justamente essa cidade, aparentemente feita de casario anónimo e indiferenciado, que me parece justificar uma nova atenção em função da recente identificação de uma outra pintura igualmente quinhentista. Refiro-me ao quadro pertencente à Kelmscott Manor Collection (Figura 3) que, em Novembro de 2010, integrou uma exposição dedicada a marfins cingaleses do século XVI realizada no Museu Rietberg de Zurique, entre cujos curadores se encontrava Annemarie Jordan Gschwend, responsável pelo seu reconhecimento temático ${ }^{11}$. Datável das últimas décadas do século XVI e de autor desconhecido, mas ao que tudo indica de origem flamenga, o quadro, hoje cortado em duas telas, representa a Rua Nova dos Mercadores, em Lisboa. Se dúvidas restassem, a famosa grade que no século XVI separava a área dos cambistas e que, por tão marcante, viria a justificar o outro topónimo por que ficou conhecida - Rua Nova dos Ferros ${ }^{12}-$ seria suficiente para garantir o reconhecimento daquela importante artéria de Lisboa.

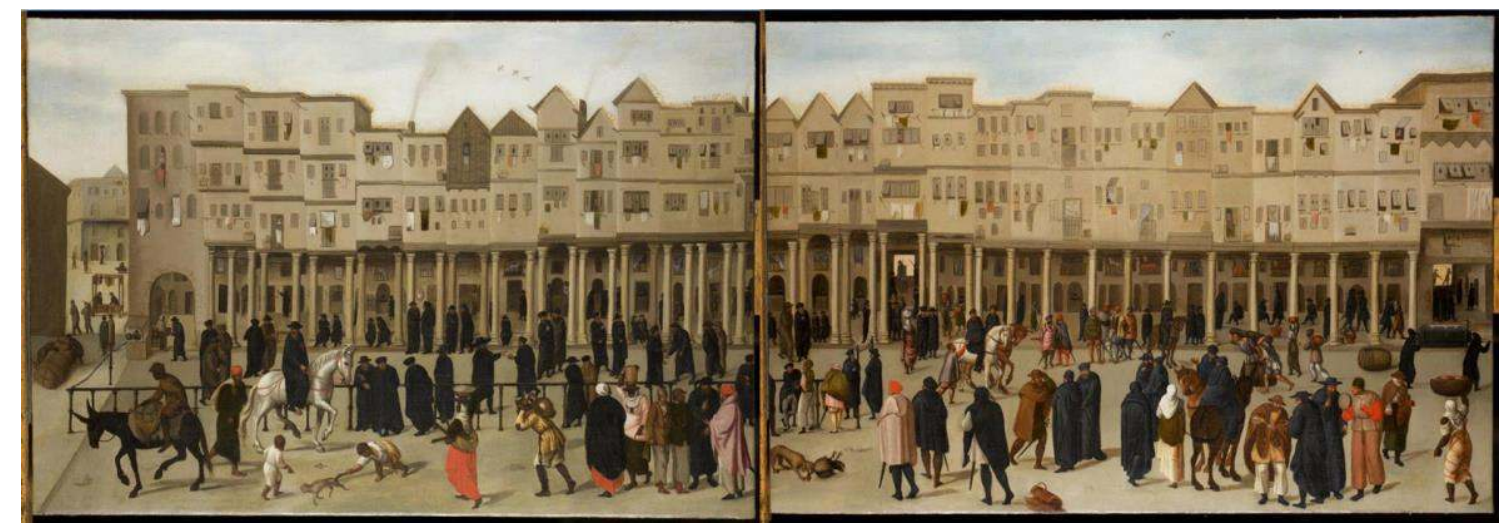

Figura 3 - Rua Nova dos Mercadores, em Lisboa. Autor anónimo, c. 1570-1590.

Londres, Kelmscott Manor Collection - Society of Antiquaries of London. (uma tela original, hoje dividida em duas)

\footnotetext{
${ }^{11}$ BELTZ, Johannes; JORDAN GSCHWEND, Annemarie - Ivories from Ceylon: luxury goods from the Renaissance. Zurich: Museum Rietberg, 2010. Já depois da realização da conferência a que este texto reporta, concretamente em Dezembro de 2015, foi lançada a obra de JORDAN GSCHWEND, Annemarie; LOWE, K.J.P. (eds.) - The Global City. On the streets of the Renaissance Lisbon. London: Paul Hoberton, 2015, onde a pintura (e o universo para que remete) é detalhadamente apresentada e estudada por vários autores. Refira-se ainda que em 2013 a mesma pintura foi reproduzida, no interior e na capa da obra de MATOS, José Sarmentos de; PAULO, Jorge Ferreira - Um sítio na Baixa. A sede do Banco de Portugal. Lisboa: Banco de Portugal, 2013.

${ }^{12}$ SILVA, A. Vieira da - As muralhas da Ribeira de Lisboa. Lisboa: Câmara Municipal, 1987 (1 ${ }^{\mathrm{a}}$ ed. 1900), vol. I, p. 97.
} 
Rasgada no reinado de D. Afonso III e reformulada algumas décadas depois por D. Dinis ${ }^{13}$, que nela concentrou o grosso do seu investimento imobiliário, a Rua Nova, invulgarmente ampla e rectilínea, sobretudo no contexto de uma cidade onde a marca islâmica seria então ainda vincadamente presente ${ }^{14}$, foi, durante toda a Idade Média, a "milhor e mais prinçipall da dicta çidade", para usarmos o testemunho de D. Afonso V. O seu calcetamento, ato então ainda muito circunscrito e pouco comum, foi ordenado por D. João II que seguiu a obra com particular interesse, não só mandando fazer uma planta "pyntada em papell" de 6 metros de comprimento, a partir da qual ele e os seus colaboradores mais próximos discutiam o andamento da obra, como também encomendando a pedra na região do Porto, seguindo o modelo que D. João I usara na Rua Formosa, acréscimo imenso de esforço e de custo só justificáveis pela excepcionalidade da rua no panorama urbano de então ${ }^{15}$.

Hieronymus Münzer ${ }^{16}$, João Brandão de $\operatorname{Buarcos}^{17}$ ou Damião de Góis são apenas alguns dos que a enalteceram por motivos diversos: pela largura ímpar, atingindo quase 9 metros; por ser ornada de ambos os lados de altos edifícios, todos de três e quatro sobrados, ou por nela se juntarem "todos os dias, comerciantes de todas as partes e povos do mundo"18. Era, efetivamente, o nervo comercial de Lisboa, nela se concentrando lojas de panos e sedas de todas as sortes, tendas de especiarias de todo o género, boticas ou livreiros. Nos sobrados de cima, continuando a seguir João Brandão, viviam inúmeros mercadores, "homens muito abastados e de grossíssimas fazendas, dinheiro e trato"19. O elevado número de escravos - que levou Baccio da Filicaia a

\footnotetext{
${ }^{13}$ Sobre a Rua Nova veja-se, SILVA, A. Vieira da - As muralhas da Ribeira de Lisboa..., pp. 91-112; CARITA, Hélder - Lisboa Manuelina e a formação de modelos urbanísticos da Época Moderna (14951521). Lisboa: Livros Horizonte, 1999, pp. 33-35 e 67-68; SILVA, Carlos Guardado da - Lisboa Medieval: a organização e estruturação do espaço urbano. Lisboa: Colibri, 2008, pp. 272 e 231.

${ }^{14}$ Sobre o processo de "cristianização da cidade islâmica", veja-se TRINDADE, Luísa - Urbanismo na composição de Portugal. Coimbra: Imprensa da Universidade, 2013.

${ }^{15}$ GONÇALVES, Iria - "Uma realização urbanística medieval: o calcetamento da Rua Nova de Lisboa". in Um olhar sobre a cidade medieval. Cascais: Patrimonia, 1996, pp. 117-137.

${ }^{16}$ MÜNZER, Jerónimo - "Viaje por España y Portugal en los años 1494 y 1495 (Conclusión), versión del latín por Julio Puyol". Boletín de la Real Academia de la Historia, tomo 84 (1924), p. 213.

${ }^{17}$ BRANDÃO (de Buarcos), João - Grandeza e abastança de Lisboa em 1552. Ed. José da Felicidade Alves. (manuscrito de 1552, $1^{\mathrm{a}}$ ed. 1923). Lisboa, Livros Horizonte, 1990, pp. 97-100.

${ }^{18}$ GÓIS, Damião de - Descrição da cidade de Lisboa. Ed. José da Felicidade Alves. (1 ${ }^{\mathrm{a}}$ ed. 1554). Lisboa: Livros Horizonte, 1988, p. 54.

${ }^{19}$ BRANDÃO (de Buarcos), João - Grandeza e abastança de Lisboa em 1552..., p. 99.
} 
Uma outra representação da Rua Nova dos Mercadores, em Lisboa:

a tábua do “martírio de S. Sebastião", de Gregório Lopes • Luísa Trindade

caracterizar Lisboa como "um jogo de xadrez, tantos os brancos quantos os negros"20-, as chamadas "negras de canastra" que, transportando os despejos domésticos à cabeça, espantavam os visitantes, ou a forma como os portugueses de bem trajavam, com longas capas negras que lhes deixavam apenas os braços de fora, como relata Jan Taccoen ${ }^{21} \mathrm{em}$ 1514, são uma nota dominante nesta, como noutras representações ${ }^{22}$ das zonas centrais e ribeirinhas da cidade de Lisboa (Figura 4).

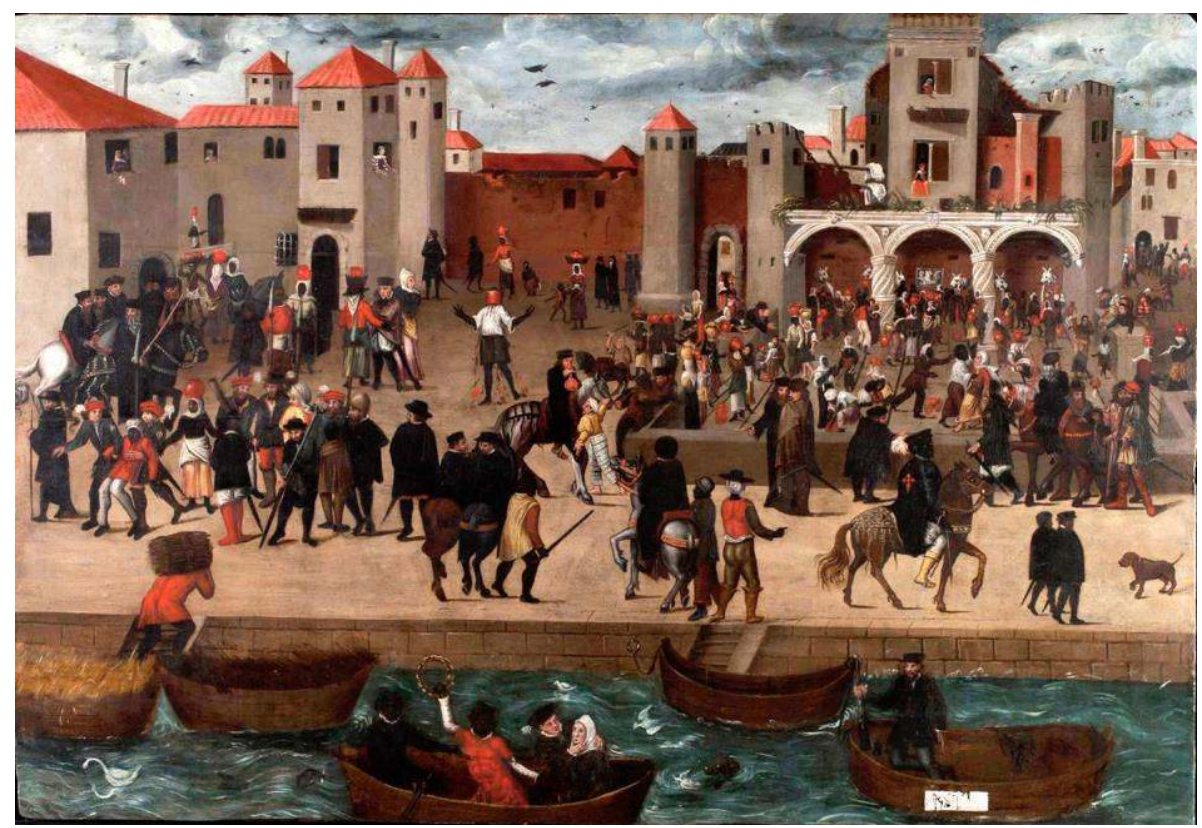

Figura 4 - Chafariz d'el Rey em Lisboa. Autor anónimo, c. 1570-80. Coleção Berardo.

Todavia, mais do que uma análise detalhada da obra ou do ambiente cosmopolita que evoca, importa aqui referir como o ângulo representado, uma vista frontal do casario, permite, pela primeira vez, observar em toda a sua especificidade a famosa Rua Nova dos Mercadores. Os edifícios de quatro e cinco pisos - ou de três e quatro sobrados para usar a terminologia da época - com lojas e sobrelojas na galeria térrea formada por esteios de pedra e madeira, mais de cento e quarenta e nove de acordo com contagem do século $\mathrm{XVIII}^{23}$; o revestimento parcial das frontarias com madeira, os chamados

\footnotetext{
${ }^{20}$ Citado por FONSECA, Jorge - "Lisboa de D. Manuel no relato de Jan Taccoen". in FONSECA, Jorge (coord.) - Lisboa em 1514: O Relato de Jan Taccoen van Zillebeke. Lisboa: Centro de História da Cultura da Universidade Nova de Lisboa e Edições Húmus, 2014, p. 100.

${ }^{21}$ FONSECA, Jorge - "Lisboa de D. Manuel no relato de Jan Taccoen...", p. 98 e 110.

${ }^{22}$ Caso da obra O Chafariz d'el Rey, pintura a óleo sobre tábua, de autor anónimo e datável de c. 157080, pertencente à Coleção Berardo.

${ }^{23}$ SILVA, A. Vieira da - As muralhas da Ribeira de Lisboa..., p. 93.
} 
Uma outra representação da Rua Nova dos Mercadores, em Lisboa:

a tábua do “martírio de S. Sebastião", de Gregório Lopes • Luísa Trindade

"fromtaes de tavoado"24 ou os ressaltos das fachadas, soluções construtivas tipicamente medievais; a diferente altura dos edifícios ou a tipologia das janelas, cerradas por portadas de madeira basculantes, muitas delas dotadas de pequenas aberturas centrais, destinadas a deixar passar alguma luz - são características que, em conjunto, descrevem uma realidade concreta, documentam o espaço e o tornam reconhecível.

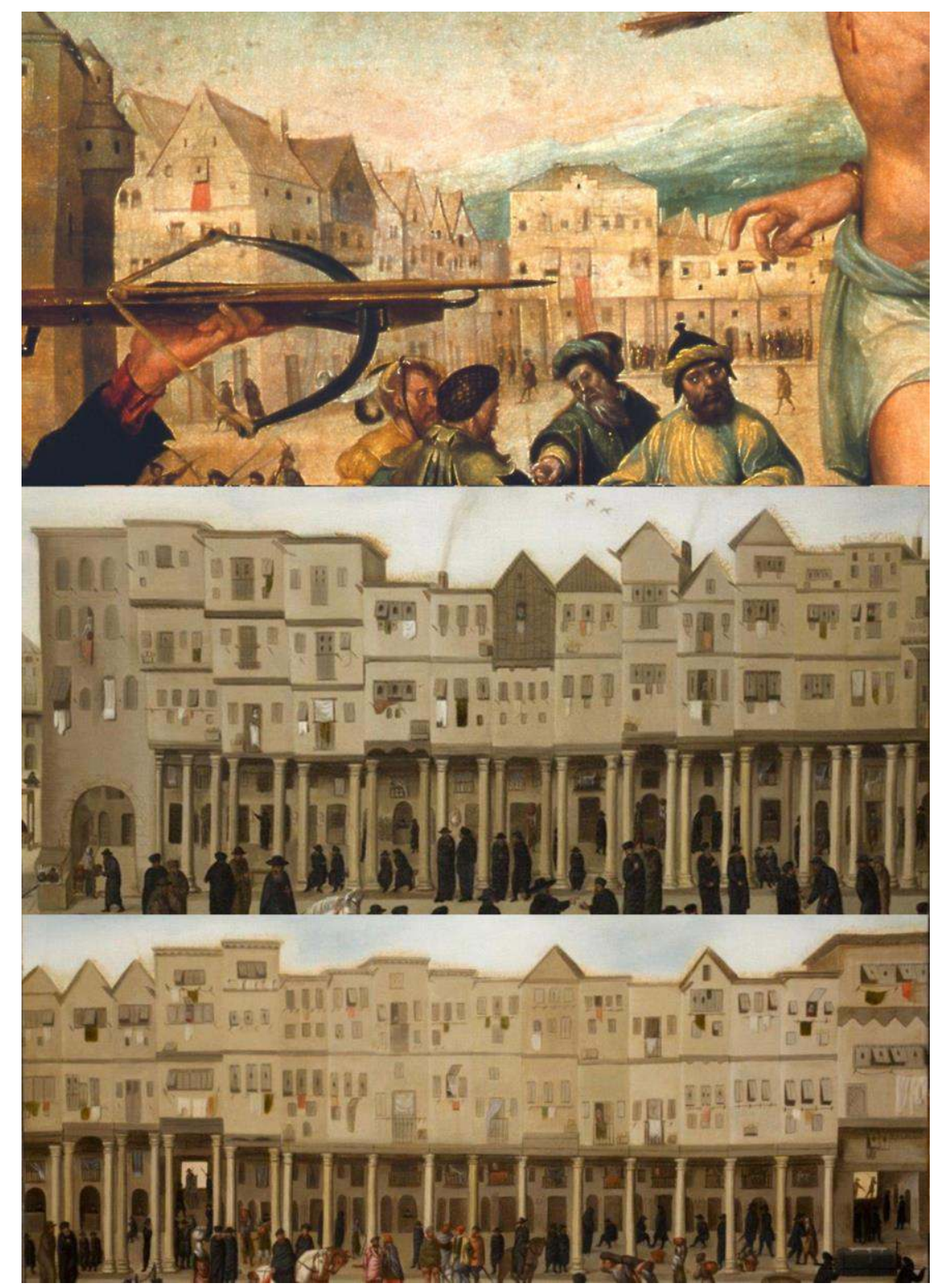

Figura 5 - Comparação entre as arquiteturas de fundo da tábua do Martírio de S. Sebastião, de Gregório Lopes e a representação da Rua Nova dos Mercadores, da Kelmscott Manor Collection.

\footnotetext{
${ }^{24}$ Sobre o uso da madeira veja-se TRINDADE, Luísa - A casa corrente em Coimbra. Dos finais da Idade Média aos inícios da Época Moderna. Coimbra: Câmara Municipal, 2002 p. 86 ss.
} 
Curiosamente, todas essas características, sem exceção, marcam presença na tábua do Convento de Cristo, realizada cerca de quarenta anos antes. O cotejo entre ambas as pinturas (Figura 5) permite-nos abandonar a ideia de Gregório Lopes ter representado uma cidade anónima, identificando, pelo contrário, a representação da cidade habitada pelo próprio pintor, - recorde-se que residia em Lisboa, junto ao mosteiro de S. Domingos, a escassas centenas de metros da Rua Nova dos Mercadores $^{25}$. Identificação que me parece ter passado até agora despercebida ${ }^{26}$ mas que, verdadeiramente, só seria possível a partir da descoberta da tela flamenga, ocorrida há cerca de cinco anos atrás. Lisboa quinhentista, portanto. Essa cidade que, sobretudo entre o Rossio e a recém renovada frente ribeirinha ${ }^{27}$, com passagem obrigatória pelas ruas Nova d'El Rei e Nova dos Mercadores corporizava, na década de 1530, um dos principais entrepostos comerciais de toda a Europa, onde diariamente fundeavam caravelas e carracas vindas de todas as partes do mundo conhecido (Figura 6). Lisboa, cabeça do Império, podia certamente repartir o espaço narrativo da tábua com Roma, essa outra caput mundi. Síntese de dois espaços que, simultaneamente, figuravam de forma particularmente legível o percurso da famosa relíquia de S. Sebastião: de Roma a Lisboa.

\footnotetext{
${ }^{25}$ CAETANO, Joaquim Oliveira - O que Janus Via. Rumos e cenários da pintura portuguesa (15351570). Lisboa: Faculdade de Ciências Sociais e Humanas da Universidade Nova de Lisboa, 1996. Dissertação de Mestrado, p. 92.

${ }^{26}$ Notícia originalmente publicada em TRINDADE, Luísa - "Desenho: discurso e instrumento". in ROSSA, Walter; RIBEIRO, Margarida Calafate (coord.) - Patrimónios de Influência Portuguesa: modos de olhar. Coimbra, Lisboa, Niterói: Imprensa da Universidade de Coimbra, Fundação Calouste Gulbenkian e Editora da Universidade Federal Fluminenese, 2015, pp. 401-452.

${ }^{27}$ Sobre a renovação da Lisboa ribeirinha ao tempo de D. Manuel veja-se, CARITA, Hélder - Lisboa Manuelina e a formação de modelos urbanísticos da Época Moderna (1495-1521). Lisboa: Livros Horizonte, 1999; SENOS, Nuno - O Paço da Ribeira 1501 - 1581. Lisboa: Editorial Notícias, 2002; CAETANO, Carlos - A Ribeira de Lisboa na Época da Expansão Portuguesa (Séculos XV a XVIII). Lisboa: Pandora, 2004.
} 
Uma outra representação da Rua Nova dos Mercadores, em Lisboa:

a tábua do “martírio de S. Sebastião", de Gregório Lopes • Luísa Trindade

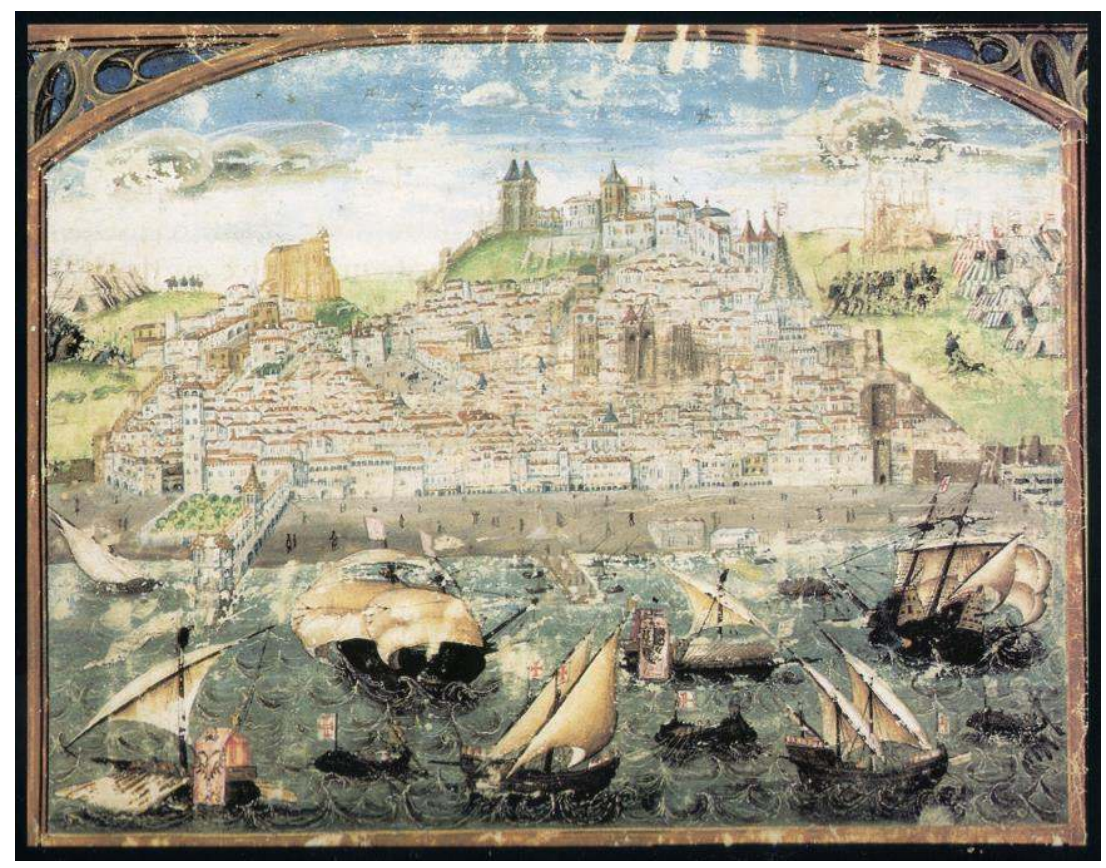

Figura 6 - Vista de Lisboa, Frontispício da Crónica de D. Afonso Henriques, de Duarte Galvão, atribuída a António de Holanda, 1535-1545.

Cascais, Casa-Museu Conde Castro Guimarães, Inv. 14.

A representação da Rua Nova dos Mercadores, todavia, não terá pretendido ser um retrato fiel do espaço a que alude já que os edifícios, fugindo ao plano linear, conformam uma ampla praça em $\mathrm{U}$, ou, de forma mais precisa, um terreiro, cujo especial alongamento perspético foi já cabalmente explicado por Joaquim Caetano ${ }^{28}$, como fazendo parte da solução encontrada por Gregório Lopes para corrigir os efeitos da forma enviesada como, no corredor estreito e curvo da Charola, o observador acedia ao quadro. A composição do Martírio de S. Sebastião seria assim o resultado da utilização livre de um conjunto de referências, algumas longínquas, outras coevas e familiares ao pintor, no que não seria, aliás, um recurso invulgar na obra de Gregório Lopes, como foi sublinhado por Joaquim Caetano ou Paulo Pereira: na Degolação de S. João Baptista, de cerca de 1536 (Figura 7), fica bem patente a colagem de referências várias $^{29}$ : a igreja do Santo Sepulcro, na sua iconografia genérica de já longa tradição planta centrada, corpo superior rasgado por duas janelas - surge "contaminada" por dois edifícios portugueses de manifesto impacto à época: a Galeria do Paço da Ribeira, em

\footnotetext{
${ }^{28}$ CAETANO, Joaquim Oliveira - O que Janus Via..., pp. 99-101.

${ }^{29}$ CAETANO, Joaquim Oliveira - O que Janus Via..., p. 96 e PEREIRA, Paulo - A Fábrica Medieval..., vol 1. p. 206.
} 
Lisboa, e a parte superior da fachada da igreja da Graça, erguida por Nicolau Chanterene apenas um ano antes, em Évora, cidade onde a corte permaneceria no decorrer de quase toda essa década.

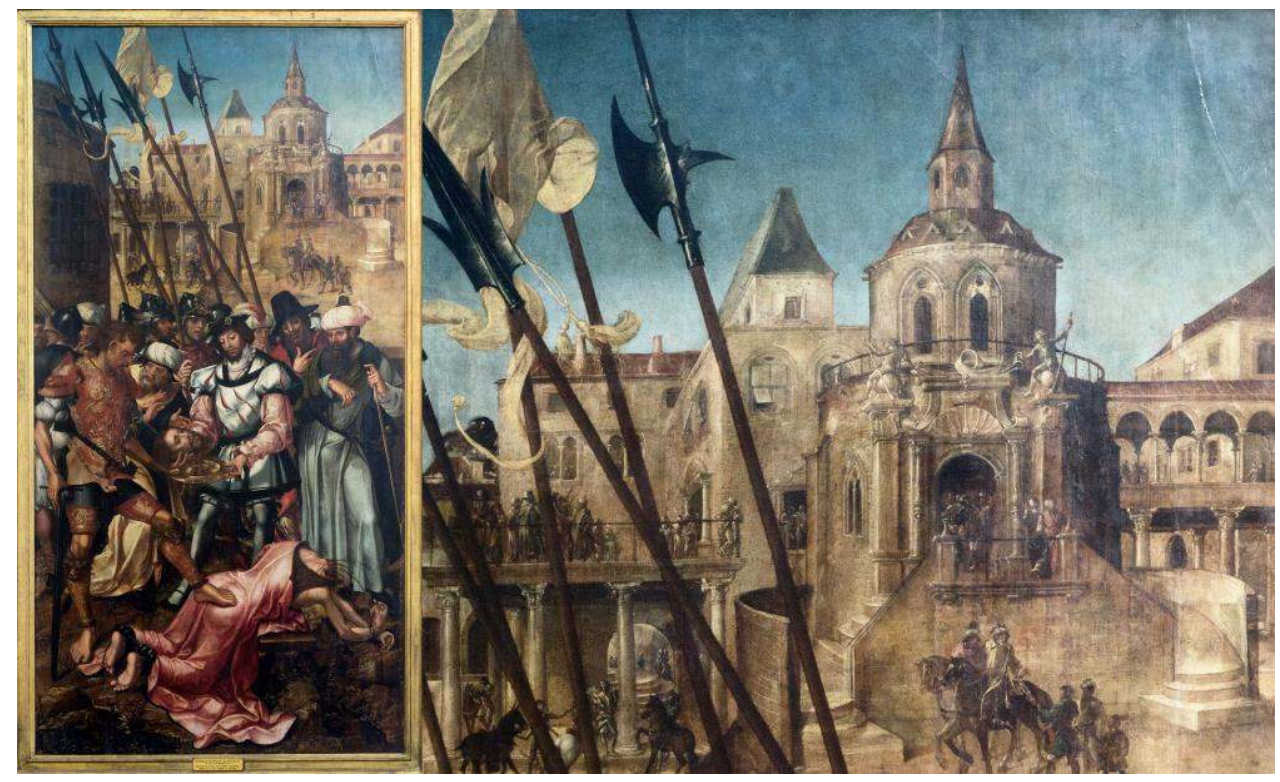

Figura 7 - Degolação de S. João Baptista, Gregório Lopes, 1536-1538 e pormenor das arquiteturas representadas no plano de fundo. Tomar, Igreja de S. João Baptista. Fotografia de Dias dos Reis.

São citações livres e abreviadas, frequentes no grupo de pintores lisboetas de Quinhentos. Espaços e arquiteturas que se manipulam, sujeitando-os à composição geral e à máxima eficácia narrativa. Por vezes subtis e discretas. Veja-se como, no grupo de pinturas dedicadas aos Santos Mártires de Lisboa $^{30}$ onde pormenores do Paço da Ribeira (Figura 8) são por diversas vezes replicados, a orientação da escada do Paço, na tábua do Arrastamento pelas ruas, surge invertida ou espelhada ${ }^{31}$; já na Chegada das Relíquias de Santa Auta ao Mosteiro da Madre de Deus, a veracidade da portada da igreja tem por contraponto a localização fictícia do Tejo, não à frente como verdadeiramente acontece, mas atrás, única forma de tornar visível essa proximidade ao rio, deixando simultaneamente livre o primeiro plano para a Santa e o cortejo processional ${ }^{32}$ (Figura 9).

\footnotetext{
30 Pertencentes ao espólio do Museu Carlos Machado, em Ponta Delgada, as pinturas representam o Anúncio do Martírio, o Desembarque em Lisboa, a Flagelação e o Arrastamento pelas ruas. BATORÉO, Manuel - "A iconografia dos Santos Mártires de Lisboa em quatro pinturas do século XVI: linguagem e significados". Cultura, Vol. 27 (2010), pp. 187-199.

${ }^{31}$ PEREIRA, Paulo - A Fábrica Medieval..., vol. II, p. 884.

${ }^{32}$ Ibidem, vol 1. p. 181.
} 
Uma outra representação da Rua Nova dos Mercadores, em Lisboa:

a tábua do “martírio de S. Sebastião", de Gregório Lopes • Luísa Trindade

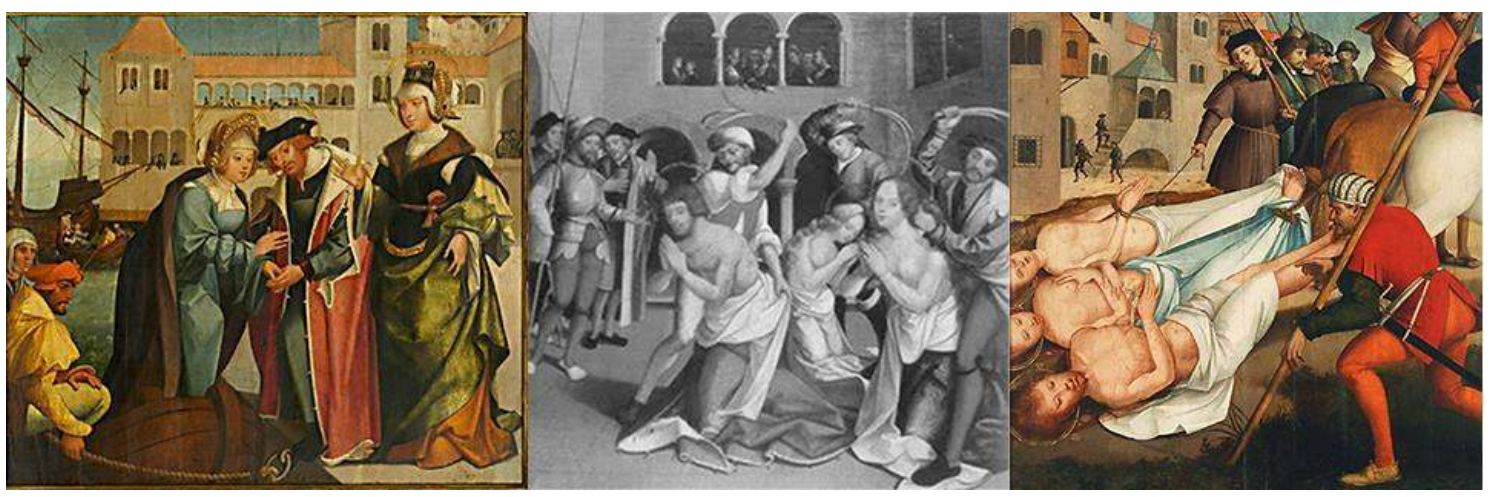

Figura 8 - Santos Mártires Veríssimo, Máxima e Júlia - Desembarque em Lisboa, Flagelação e Arrastamento pelas ruas, oficina lisboeta, c. 1530-1540.

Ponta Delgada, Museu Carlos Machado.

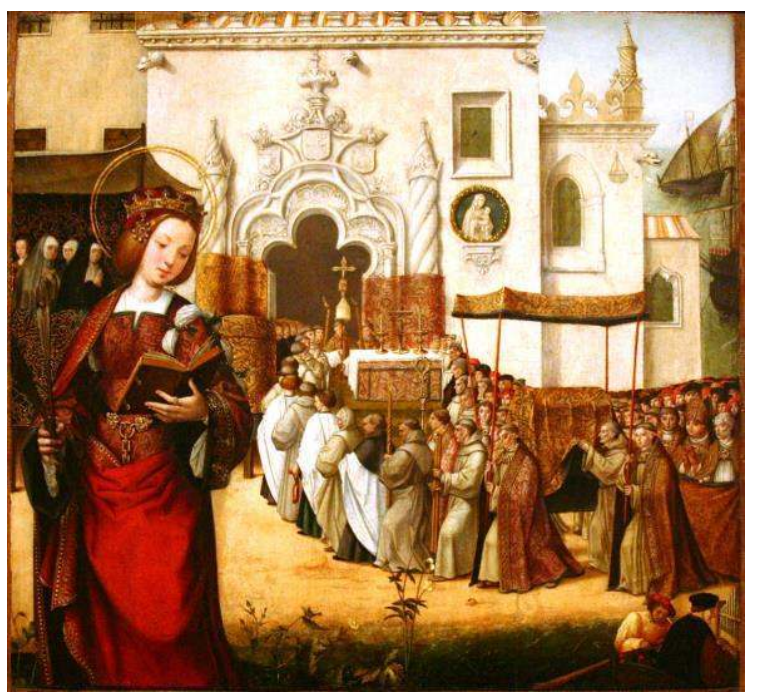

Figura 9 - Painel do Retábulo de Santa Auta. Chegada das relíquias ao Mosteiro da Madre de Deus (c.1518-1520). Lisboa, Museu Nacional de Arte Antiga, Inv. 1492 Pint.

Mais sugestivo, por constituir justamente um estratagema idêntico ao que Gregório Lopes adopta, se bem que pela forma inversa, é a representação do Paço da Ribeira no fólio 25 do Livro de Horas dito de D. Manuel (Figura 10) ${ }^{33}$, de António de Holanda, certamente ajudado por outros pintores, porventura até o próprio Gregório Lopes, como foi já aventado ${ }^{34}$. A figuração de toda a estrutura monumental do Paço, desde o torreão ao corpo norte onde se concentrava o grosso dos aposentos da corte, passando pela

${ }^{33}$ Livro de Horas dito de D. Manuel, Museu Nacional de Arte Antiga, Inv. 14, fl. 25. Sobre este códice veja-se MARKL, Dagoberto - Livro de Horas de D. Manuel, Estudo Introdutório. Lisboa: Crédito Predial Português e Imprensa Nacional-Casa da Moeda, 1983.

${ }^{34}$ PEREIRA, Paulo - A Fábrica Medieval..., vol 1. p. 111. 
longa varanda, obrigou a um rebatimento horizontal, ou planificação das frentes construídas em ângulo recto ${ }^{35}$. No martírio, ao contrário, um só plano surge dobrado duas vezes, assim configurando as três frentes do terreiro em U.

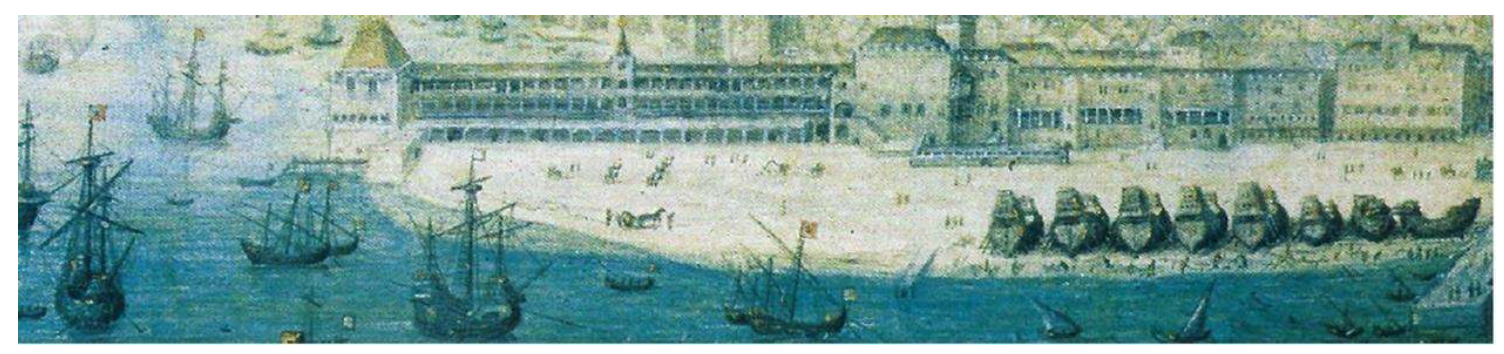

Figura 10 - Paço da Ribeira, em Lisboa. Livro de Horas dito de D. Manuel, atribuído a António de Holanda, 1517 - 1551. Lisboa, Museu Nacional de Arte Antiga N. ${ }^{\circ}$ de Inv. 14/fl. 25v.

Mas voltemos às duas pinturas, a portuguesa e a flamenga: a similitude entre ambas funciona como confirmação recíproca, sobretudo porque nada parece ligá-las entre si, cronologia, autoria ou comitente. O único elo é o tema: ambas remetem, ainda que uma com total protagonismo, outra de forma discreta, para um espaço real e concreto: a Rua Nova dos Mercadores, em Lisboa, nos finais da década de 30 e ao findar do século XVI. Esta nova face da Rua Nova dos Mercadores levanta, porém, uma outra questão, pois desde a Exposição da Arte Sacra Ornamental ${ }^{36}$, realizada em Lisboa em 1895, que a referida artéria tinha rosto: a representação do fólio 130 do Livro de Horas dito de D. Manuel (Figura 11), já aqui referido a propósito do Paço da Ribeira. A imagem integra o conjunto que ilumina o Ofício dos Mortos, de há muito tido como iconograficamente complexo, mais ainda após a profunda revisão operada por Vasco Graça Moura ${ }^{37}$ ao identificar, no conjunto, episódios de duas exéquias distintas: a trasladação do corpo de D. João II de Silves para a Batalha, em 1499, e as de D. Manuel, ocorridas em Dezembro de 1521. Apesar das controvérsias geradas, um aspeto é consensual: os espaços urbanos que preenchem as tarjas representam arruamentos e edifícios de Lisboa.

\footnotetext{
${ }^{35}$ Ibidem, vol. II, p. 885.

${ }^{36}$ Catálogo da Sala de Sua Majestade El-Rei. Exposição de Arte Sacra Ornamental. Lisboa: Typographia Castro Irmão, 1895.

${ }^{37}$ MOURA, Vasco Graça - "Damião de Góis e o Livro de Horas dito de D. Manuel". Arte Ibérica, Ano 3, n. 24 (Maio 1999) (Separata Arte Ibérica).
} 


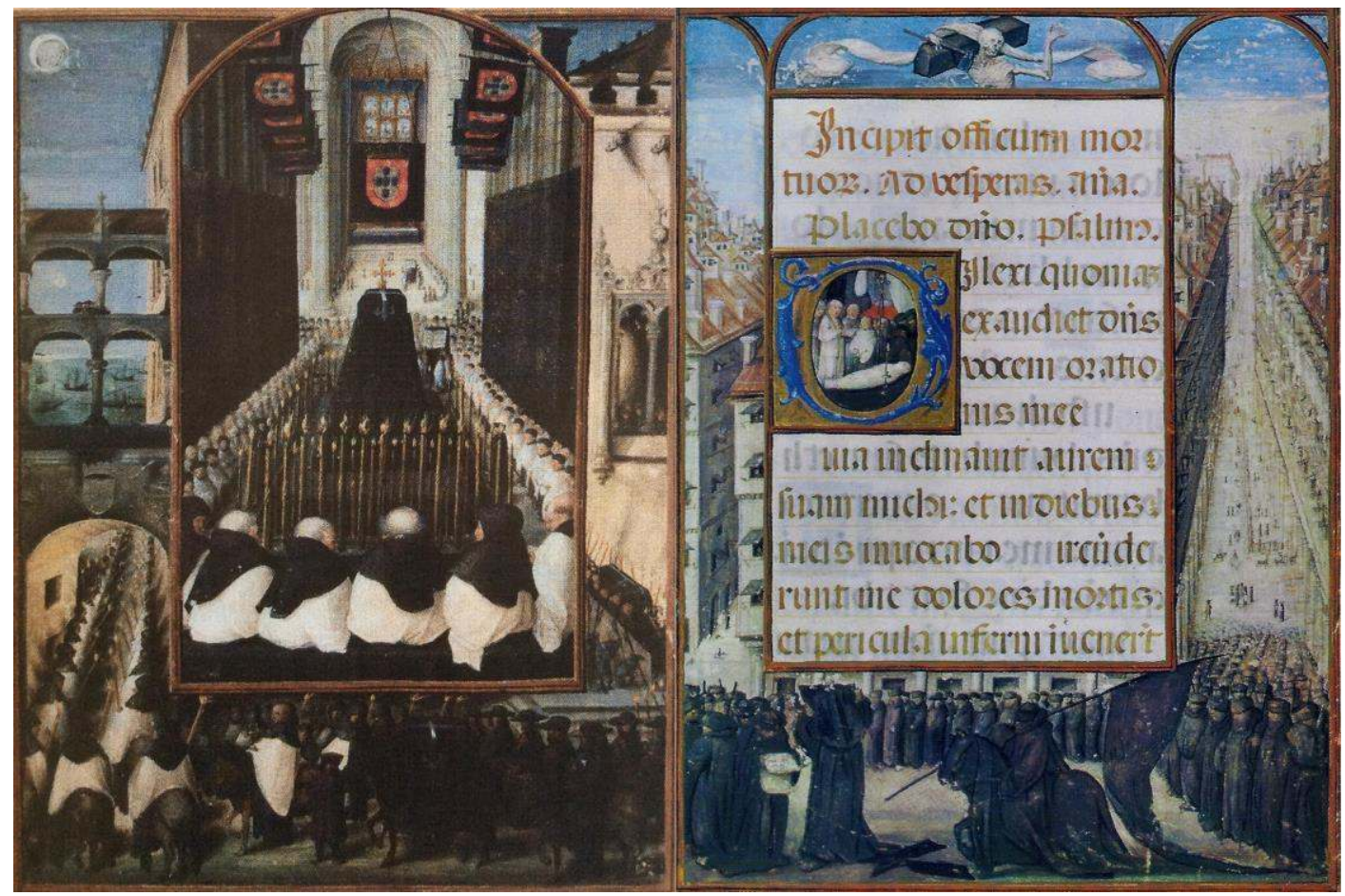

Figura 11 - Livro de Horas dito de D. Manuel (Ofício dos Mortos), atribuído a António de Holanda, 1517 - 1551. Lisboa, Museu Nacional de Arte Antiga N. ${ }^{\circ}$ de Inv. 14/129v. e 130.

Na iluminura do fólio 129, o cortejo fúnebre de D. Manuel abandona o Paço da Ribeira pelas escadas que no ângulo davam acesso à sala grande e, desenhando uma curva de 180 graus, passa debaixo do Arco dos Paços, situado no extremo norte da extensa varanda (Figura 12) ${ }^{38}$. Daí, a procissão noturna seguiria em direção ao Mosteiro dos Jerónimos onde, de acordo com a vontade expressa do monarca, o seu corpo seria sepultado. Também no fólio 130, onde surge representado o ritual da Quebra dos Escudos, procissão diurna realizada quatro dias após a morte do monarca, se torna claro que o pintor utilizou um cenário autêntico: o das ruas da Baixa lisboeta no tempo de D. João III. Socorrendo-se de um arrojado jogo perspético, o iluminador acentua a monumentalidade desta parte da cidade, até há muito pouco tempo consensualmente identificada com a Rua Nova dos Mercadores. A rua paralela a esta, por seu lado, era sistematicamente remetida para o anonimato, não parecendo relevante na composição geral.

\footnotetext{
${ }^{38}$ Sobre o Paço da Ribeira e as suas representações no Livro de Horas dito de D. Manuel veja-se SENOS, Nuno - O Paço da Ribeira..., sobretudo pp. 90-91 e 100-101.
} 


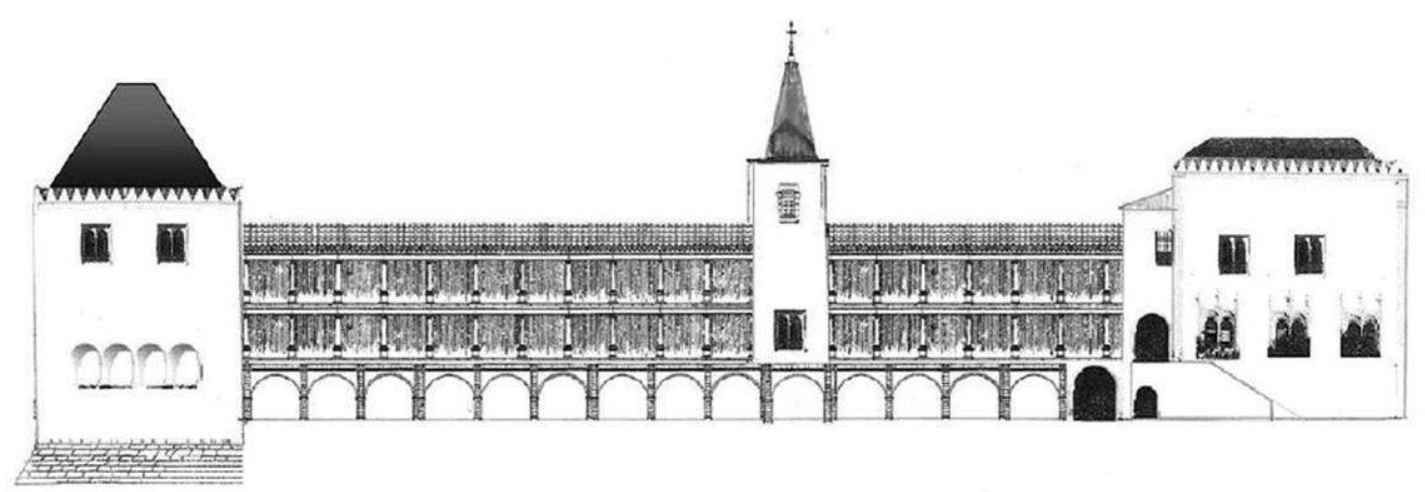

Figura 12 - Reconstituição do Paço da Ribeira segundo Paulo Pereira, A Fábrica Medieval Concepção e Construção da Arquitectura Portuguesa (1150-1550), 2011, vol. 2, p. 894.

Em contracorrente com a opinião generalizada que identifica - quase sem questionamento - esta representação com a Rua Nova dos Mercadores, Pedro $\mathrm{Cid}^{39}$, num breve mas incisivo artigo escrito em 2000, avançou a hipótese de se tratar, afinal, de uma outra Rua Nova que, perpendicular à anterior, estabelecia a ligação direta entre o Rossio e a Ribeira: a Rua Nova d'El Rei. Não é este o lugar para dirimir detalhadamente os argumentos que sustentam o debate, mas é certamente o lugar para tentar perceber as implicações que as duas outras pinturas da Rua Nova dos Mercadores - a flamenga e a de Gregório Lopes - aportam a este debate em torno do fólio 130 e, por elas, tomar posição, com novos fundamentos, na esteira da proposta de Pedro Cid.

Vale a pena olhar de novo para a tão conhecida iluminura. A vista é captada a partir de um largo, tendo o observador à sua frente o topo de um quarteirão com uma rua de cada lado. Embora da artéria à esquerda apenas se entreveja a entrada, fica claramente evidenciada a altura dos edifícios, bem como a dos que por trás parecem subir uma encosta; quanto à artéria do lado direito, surge representada numa grande extensão, perdendo-se o seu remate num traço progressivamente mais difuso e esfumado. A rua é acentuadamente larga, sendo a distância entre os edifícios idêntica e regular em toda a extensão. De cada lado, erguem-se de forma ininterrupta prédios de quatro pisos, o térreo aberto em galeria. Tal como a frente dos edifícios, também a sua altura ou cércea corre uniformemente em toda a extensão. Os vãos possuem portadas basculantes e os

\footnotetext{
${ }^{39}$ CID, Pedro de Aboim Inglez - "O Livro de Horas dito de D. Manuel. Algumas precisões". História,
} Ano XXII, n. 26, (Jun. 2000), pp. 46-55. 
telhados, representados numa vertente única e regular, são coroados massivamente por chaminés e o que parecem ser águas furtadas.

Atenhamo-nos apenas em dois argumentos, um de lógica processual; outro de ordem formal. No que toca ao primeiro, e seguindo o esquema posto em prática no fólio 129, parece indiscutível a vontade do pintor em retratar o percurso do cortejo fúnebre realizado em memória do rei, a 17 de Dezembro. Como destacou Vasco Graça Moura, todas as representações deste Ofício dos Mortos indiciam a forma como o iluminador terá recebido instruções minuciosas para seguir determinados textos ${ }^{40}$. O mesmo terá acontecido neste caso sendo a cena retratada diretamente vertida da Memória da doença e enterro de el rei D. Manuel, publicada por António Caetano de Sousa, nas Provas da História Genealógica da casa Real Portuguesa ${ }^{41}$ :

\begin{abstract}
"Saíram os vereadores da cidade ao pé da casa da Câmara com as suas varas pretas nas mãos e a cavalo vinha um alferes o qual vinha coberto em um cavalo à brida todo coberto de dó de pano de linho preto e trazia a bandeira preta do dito pano de linho derribada ao ombro e a ponta dela arrastava pelo chão e vinham com ele muitos senhores e fidalgos e à porta da Sé quebraram um escudo negro; na Rua Nova quebraram outro escudo e no Rossio, na metade dele, outro. Então se tornaram pela rua da Praça da Palha e pela Correaria a pé e vindo o dito alferes assim com a bandeira a cavalo como foi à ida o alferes se foi à Câmara e os vereadores, senhores e fidalgos à Sé onde se disse missa cantada de requiem".
\end{abstract}

A ter sido seguido o relato, como tudo indica, a quebra de escudo que ocupa toda a parte inferior da tarja só pode corresponder, como bem viu Pedro Cid, à terceira e última, realizada no Rossio. De facto, a Sé não está retratada e a rua aqui figurada ficou já claramente para trás e quase integralmente esvaziada da multidão que dá corpo ao cortejo. A ter de escolher um dos três espaços onde, segundo Caetano de Sousa, ocorreu

\footnotetext{
${ }^{40}$ MOURA, Vasco Graça - "Damião de Góis e o Livro de Horas dito de D. Manuel...", p. 5.

${ }^{41}$ SOUSA, António Caetano de - "Memória da doença e enterro del Rei D. Manuel". in SOUSA, António Caetano de - Historia genealogica da Casa Real Portuguesa. Provas. (1 $1^{\text {a }}$ ed. 1735-1748). Coimbra: 1947. Tomo II. $1^{\text {a }}$ parte, pp. 384-385.
} 
a Quebra dos Escudos, este será certamente o topo sul do Rossio, percorrido momentos antes de o cortejo enveredar pelas ruas que, de novo, o levariam à Sé. Tudo ganha sentido quando mapeado na baixa da Lisboa quinhentista: o percurso, a altura dos edifícios, a subida destes pela encosta ${ }^{42}$. $\mathrm{O}$ mesmo não se verifica se partirmos do princípio de que a rua de onde sai a procissão é a Nova dos Mercadores.

Veja-se agora o argumento formal: quase sem exceção, os principais arruamentos da Baixa tinham sido intervencionados escassos anos antes por D. Manuel, no âmbito do vasto programa de reordenação urbana pensado entre 1498 e 1499 e concretizado em 1502, detalhadamente estudados, no seu conjunto, por Hélder Carita. A Rua dos Ferreiros, as ruas das Tanoarias, a Sapataria e, claro, a Rua Nova dos Mercadores. O conjunto de intervenções, realizadas em paralelo pelo rei e pela câmara, tinha como principais objectivos a regularização dos alçados, a ampliação e o enobrecimento do espaço. Assim, obrigar os proprietários, no prazo de um ano, a substituir os frontais em madeira por novas fachadas em tijolo e pedra; demolir antigos balcões ou ressaltos nas frontarias e, em seu lugar, erguer "parede direita"; alinhar os alçados, sobre esteios ou arcos, para que todas as casas fiquem "iguays e por cordel e que hua não saya mais que outra", são as medidas-chave para alcançar o que Hélder Carita caracterizou como a uniformidade formal pretendida por D. Manuel, segundo ele, bem patente na iluminura do Livro de Horas ${ }^{43}$. E aqui surge de novo uma incongruência. Recorde-se o alinhamento cronológico das três imagens: a de Gregório Lopes de 1536-39; as duas iluminuras do Ofício dos Mortos, hoje globalmente aceites como posteriores a $1545^{44}$, data da publicação do texto que serviu de base ao respetivo programa iconográfico; a da tela londrina, posterior a 1570 .

Repare-se agora como as representações de Gregório Lopes e do pintor flamengo parecem provar algo que, de resto, já se suspeitava: o alcance relativo das reformas manuelinas ${ }^{45}$. Cérceas irregulares, frontarias revestidas a madeira, ressaltos nas

\footnotetext{
${ }^{42}$ CID, Pedro de Aboim Inglez - "O Livro de Horas dito de D. Manuel...", p. 48.

${ }^{43}$ CARITA, Hélder - Lisboa Manuelina..., p. 68.

${ }^{44}$ MOURA, Vasco Graça - "Damião de Góis e o Livro de Horas dito de D. Manuel...", p. 18.

45 A título de exemplo, após o terramoto de 1755, Manuel da Maia, na sua dissertação, afirmava estarem finalmente reunidas as condições para destruir os velhos e perigosos passadiços que atravancavam a cidade de Lisboa. Passadiços ou passagens cobertas que, 255 anos antes, D. Manuel colocara no topo da
} 
fachadas, casas que avançam umas sobre as outras, são elementos presentes em ambas as representações, a primeira de 1536 a segunda de 1570 . O que prova isto? que a rua representada no Livro de Horas, em meados do século XVI, em toda a sua efetiva uniformidade, dificilmente pode ser a Rua Nova dos Mercadores. Nada obsta, todavia, a que seja a Rua Nova d'El Rei.

De facto, ao contrário da Rua Nova dos Mercadores, a Rua Nova d'El Rei era muito recente, certamente da iniciativa de D. Afonso V que, em 1466, encanou o rego que corria na zona, criando a nova artéria também por isso designada como "rua do cano nova"46. A metade norte da rua, todavia, seria ainda mais recente: embora já referida no auto de aclamação de D. João II, de $1481^{47}$, a propósito do caminho percorrido até ao Rossio, a verdade é que ainda em pleno reinado manuelino se procedia ao seu "abrimento", para usar o termo que consta na documentação régia. Em 1501, escambam-se propriedades onde o rei "manda abrir a rua", o mesmo que ordena "ao dicto afonse annes que abra a dicta rua cumprindo inteiramente o que sobre esto lhe tem mandado" 48 . Rua recente e que, pelo menos em parte do seu percurso, no mais próximo do Rossio, é aberta por desígnio do próprio D. Manuel $^{49}$, de acordo com princípios e regras bem definidas ab initio, sistemática e detalhadamente transmitidas aos que, no terreno, cumpriam a vontade régia (Figura 13). Não admira por isso que nesta, ao contrário da velha Rua Nova dos Mercadores, os princípios urbanísticos manuelinos pudessem ser facilmente postos em prática. O que explica que possa ver-se nesta iluminura uma estrutura larga e rectilínea, de fachadas claramente disciplinadas, uniformes em altura e perfil. Um elemento, todavia, fragiliza este raciocínio. Os ferros! O gradeamento longitudinal que, como referimos já, existia no lado oriental da Rua Nova dos Mercadores, desde o Arco dos Barretes até ao Pelourinho, e que resguardava a área dedicada à banca e à finança. Como conjugar os dois aspetos? Os que sustentam a identificação da artéria representada como a Rua Nova d'El Rei, formais e processuais, e

sua lista de elementos a destruir. FRANÇA, José Augusto - Lisboa Pombalina e o Iluminismo. Lisboa: Bertrand, 1987, p. 84.

${ }^{46}$ SILVA, Carlos Guardado da - Lisboa Medieval..., p. 173.

${ }^{47}$ CID, Pedro de Aboim Inglez - "O Livro de Horas dito de D. Manuel...", p. 52.

48 VITERBO, Francisco Sousa - Dicionário histórico e documental dos arquitectos, Engenheiros e construtores portugueses. (Fac-símile da ed. de 1922). Lisboa: Imprensa Nacional Casa da Moeda, 1988, vol. III, pp. 312-318.

${ }^{49}$ CARITA, Hélder - Lisboa Manuelina..., pp. 75-78. 
aquele que constitui indiscutivelmente um elemento identitário da Rua Nova dos Mercadores?

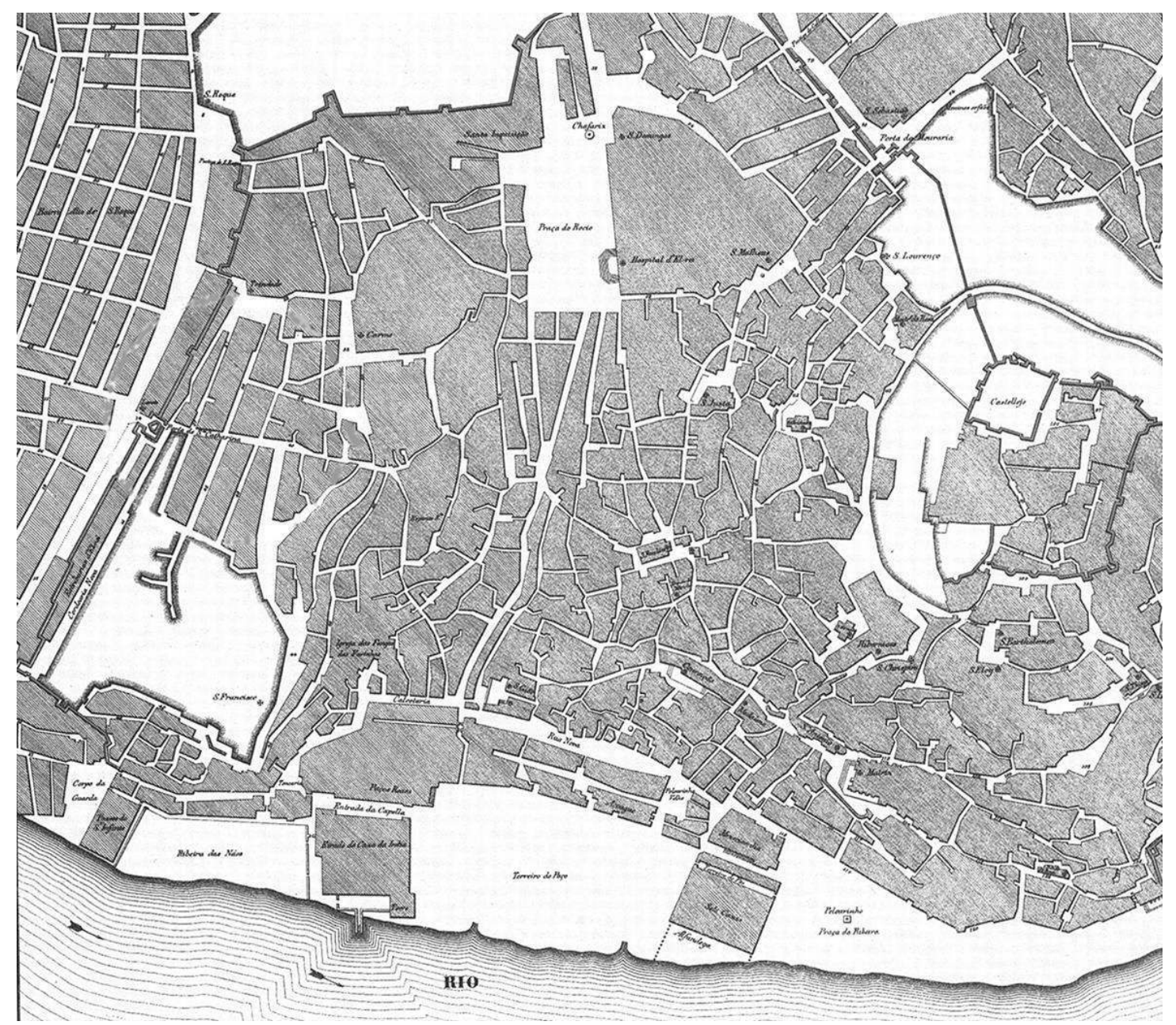

Figura 13 - Planta de Lisboa (pormenor). João Nunes Tinouco, 1650.

No campo conjectural, é possível estar-se, uma vez mais, perante a estratégia de composição a partir de referências múltiplas, já anteriormente detectada em obras de Gregório Lopes ou de outros pintores seus contemporâneos. Composição a partir de referências múltiplas, que resulta numa síntese elucidativa e tão genericamente verdadeira quanto detalhadamente falsa. Somam-se partes de realidades distintas que se compõem livremente e constrói-se um todo novo, uma realidade outra e que, embora falsa, evoca como nenhuma outra a realidade conhecida: o coração da Lisboa quinhentista, aqui apresentado pela junção das suas duas mais emblemáticas ruas.

Repare-se como, neste mesmo contexto, uma manipulação aproximada pode ser detectada no fólio 129, justamente aquele que antecede o que agora discutimos: por 


\footnotetext{
Uma outra representação da Rua Nova dos Mercadores, em Lisboa:

a tábua do "martírio de S. Sebastião", de Gregório Lopes - Luísa Trindade
}

entre os arcos da varanda do paço manuelino vê-se, a perder de vista, o Rio Tejo. Rio esse que estava efetivamente muito perto, envolvendo aliás o torreão de remate, erguido por Diogo de Arruda. Mas o Tejo corria perpendicular à varanda, não por detrás dela, a não ser a uma distância considerável quando a costa desenhava uma reentrância. Assim, entre o topo norte da varanda, cujos arcos são representados na iluminura e a vista do rio interpunham-se, criando necessariamente barreiras visuais, o jardim do Paço, a Ribeira das Naus e os quarteirões erguidos por D. Manuel em Cataquefarás. Como na tábua da Chegada das Relíquias de Santa Auta à Madre de Deus, já anteriormente referida, o que verdadeiramente importava era a referência imediata ao topos, marcado em ambos os casos pela proximidade ao Tejo, rio que era em Quinhentos uma quase metonímia de Lisboa.

Concluindo, a identificação de uma pintura até agora desconhecida permite hoje rever as arquiteturas pintadas por Gregório Lopes na tábua que realizou para o Convento de Cristo em Tomar. Através de ambas, a famosa Rua Nova dos Mercadores, em Lisboa, ganha um novo rosto. Mas tal vem colocar necessariamente em causa o que até agora, quase sem exceção, se acreditava ser a sua única e fiel representação, integrada no Livro de Horas dito de D. Manuel. Representação que não perde com isso qualquer importância já que, pelo mesmo raciocínio, passa a ser a única vista conhecida da Rua Nova d'El Rei. E nessa conquista vã por um qualquer primeiro lugar, cabe agora a Gregório Lopes, na tábua que pintou para o Convento de Cristo, o estatuto de autor da mais antiga - pelo menos conhecida - representação da Rua Nova dos Mercadores.

\section{Referências bibliográficas:}

\section{Fontes}

BRANDÃO (de Buarcos), João - Grandeza e abastança de Lisboa em 1552. Ed. José da Felicidade Alves (manuscrito de 1552, $1^{\text {a }}$ ed. 1923). Lisboa, Livros Horizonte, 1990.

GÓIS, Damião de - Descrição da cidade de Lisboa. Ed. José da Felicidade Alves (1 ${ }^{\text {a }}$ ed. 1554). Lisboa: Livros Horizonte, 1988. 
HOLANDA, Francisco de - Da Fábrica que falece à cidade de Lisboa. Ed. José da Felicidade Alves. (manuscrito de 1571, $1^{\text {a }}$ ed. de 1879). Lisboa: Livros Horizonte, 1984.

MÜNZER, Jerónimo - "Viaje por España y Portugal en los años 1494 y 1495

(Conclusión), versión del latín por Julio Puyol". Boletín de la Real Academia de la Historia. Madrid. Tomo 84 (1924), pp. 197-279.

"MEMÓRIA da doença e enterro del Rei D. Manuel". in SOUSA, António Caetano de Historia genealogica da Casa Real Portuguesa. Provas ( $1^{\text {a }}$ ed. 1735-1748). Tomo II. Coimbra, 1947.

VITERBO, Francisco Sousa - Dicionário histórico e documental dos arquitectos, Engenheiros e construtores portugueses. (Fac-símile da ed. de 1922). Lisboa: Imprensa Nacional Casa da Moeda, 1988.

\section{Estudos}

BATORÉO, Manuel - "A iconografia dos Santos Mártires de Lisboa em quatro pinturas do século XVI: linguagem e significados". Cultura, Vol. 27 (2010), pp. 187-199.

CAETANO, Carlos - A Ribeira de Lisboa na Época da Expansão Portuguesa (Séculos XV a XVIII). Lisboa: Pandora, 2004.

CAETANO, Joaquim Oliveira - O que Janus Via. Rumos e cenários da pintura portuguesa (1535-1570). Lisboa: Faculdade de Ciências Sociais e Humanas da Universidade Nova de Lisboa, 1996. Tese de Mestrado.

CARITA, Hélder - Lisboa Manuelina e a formação de modelos urbanísticos da Época Moderna (1495-1521). Lisboa: Livros Horizonte, 1999.

CARVALHO, José Adriano de Freitas - "Os recebimentos de relíquias em S. Roque (Lisboa 1588) e em Santa Cruz (Coimbra 1595). Relíquias e espiritualidade. E alguma ideologia". Via spiritus, n. 8 (2001), pp. 95-156.

CARVALHO, José Alberto Seabra de - Gregório Lopes. Pintura Portuguesa do século XVI. Lisboa: Edições Inapa, 1999.

CATÁLOGO da Sala de Sua Majestade El-Rei. Exposição de Arte Sacra Ornamental. Lisboa: Typographia Castro Irmão, 1895.

CID, Pedro de Aboim Inglez - "O Livro de Horas dito de D. Manuel. Algumas precisões". História, Ano XXII, n. 26, (Jun. 2000) pp. 46-55. 
FONSECA, Jorge - "Lisboa de D. Manuel no relato de Jan Taccoen". in FONSECA, Jorge (coord.) - Lisboa em 1514: O Relato de Jan Taccoen van Zillebeke. Lisboa: Centro de História da Cultura da Universidade Nova de Lisboa e Edições Húmus, 2014, pp. 91-113.

FRANÇA, José Augusto - Lisboa Pombalina e o Iluminismo. Lisboa: Bertrand, 1987.

GONÇALVES, Iria - "Uma realização urbanística medieval: o calcetamento da Rua Nova de Lisboa". in GONÇALVES, Iria - Um olhar sobre a cidade medieval. Cascais: Patrimonia, 1996, pp. 117-137.

JORDAN GSCHWEND, Annemarie Jordan; LOWE, K.J.P. (eds) - The Global City. On the streets of the Renaissance Lisbon. London: Paul Hoberton, 2015.

MARKL, Dagoberto - Livro de Horas de D. Manuel, Estudo Introdutório. Lisboa: Crédito Predial Português e Imprensa Nacional - Casa da Moeda, 1983.

MATOS, José Sarmentos de; PAULO, Jorge Ferreira - Um sítio na Baixa. A sede do Banco de Portugal. Lisboa: Banco de Portugal, 2013.

MOURA, Vasco Graça - "Damião de Góis e o Livro de Horas dito de D. Manuel". Arte Ibérica, Ano 3, n. 24 (Maio 1999) (Separata Arte Ibérica).

PEREIRA, Paulo - A Fábrica Medieval. Concepção e Construção da Arquitectura Portuguesa (1150-1550). Lisboa: Faculdade de Arquitetura da Universidade de Lisboa, 2011. Tese de Doutoramento, 3 vols.

SENOS, Nuno - O Paço da Ribeira 1501 - 1581. Lisboa: Editorial Notícias, 2002.

SILVA, A. Vieira da - As muralhas da Ribeira de Lisboa (1 ${ }^{\text {a }}$ ed. 1900). Lisboa: Câmara Municipal, 1987.

SILVA, Carlos Guardado da - Lisboa Medieval: a organização e estruturação do espaço urbano. Lisboa: Colibri, 2008.

TRINDADE, Luísa - "Desenho: discurso e instrumento". in ROSSA, Walter; RIBEIRO, Margarida Calafate (coord.) - Patrimónios de Influência Portuguesa: modos de olhar. Coimbra, Lisboa, Niterói: Imprensa da Universidade de Coimbra, Fundação Calouste Gulbenkian e Editora da Universidade Federal Fluminenese, 2015, pp. 401-452.

TRINDADE, Luísa - A casa corrente em Coimbra. Dos finais da Idade Média aos inícios da Época Moderna. Coimbra: Câmara Municipal, 2002.

- URBANISMO na composição de Portugal. Coimbra: Imprensa da Universidade, 2013. 


\section{COMO CITAR ESTE ARTIGO / HOW TO QUOTE THIS ARTICLE}

\section{Referência electrónica:}

TRINDADE, Luísa - "Uma outra representação da Rua Nova dos Mercadores, em Lisboa: a tábua do "martírio de S. Sebastião", de Gregório Lopes".

Medievalista [Em linha]. N. 20 (Julho - Dezembro 2016). [Consultado dd.mm.aaaa].

Disponível em

http://www2.fcsh.unl.pt/iem/medievalista/MEDIEVALISTA20/trindade2004.html ISSN 1646-740X.

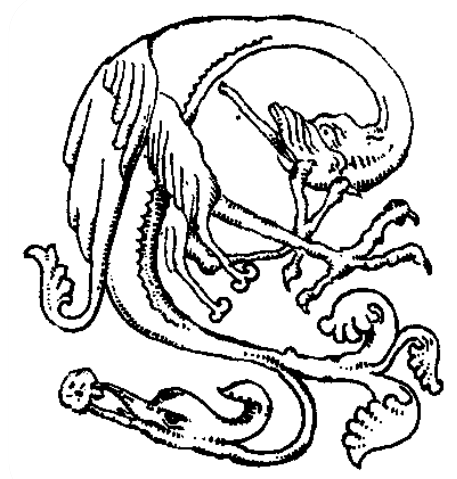

